\title{
KESALAHAN SISWA PADA OPERASI PENJUMLAHAN DAN PENGURANGAN PECAHAN DI KELAS VI SEKOLAH DASAR
}

\author{
Ni Luh Sakinah Nuraini \\ Suhartono \\ Yuniawatika \\ Jurusan KSDP, Fakultas Ilmu Pendidikan, Universitas Negeri Malang \\ Jalan Semarang No.5 Malang \\ e-mail: niluh.sakinah.fip@um.ac.id
}

\begin{abstract}
The aimed of this research is to describe the mistakes of the students grade VI in elemetary school that is related to addition and subtraction fraction operation and the causal factors. This research used explanatory design. the data is in the form of test. The result of this research indicated that $61 \%$ students do mistakes in addition fraction operation and $63,3 \%$ students do mistakes in subtraction fraction operation. The mistakes consist of misprochedure, misconception, misinterpretation of the directions, careless, wrong implementation, and unstudied. According to those datum, the result of discussion can be summed up that the mistakes of the students in addition fraction operation reach $61 \%$ and subtraction fraction operation reach $63,3 \%$.
\end{abstract}

Keyword: students' mistakes, addition, subtraction, fractions.

\begin{abstract}
Abstrak: Tujuan penelitian ini adalah mendeskripsikan kesalahan siswa kelas VI SD terkait dengan operasi penjumlahan dan pengurangan pecahan serta faktor penyebabnya. Penelitian ini menggunakan rancangan explanatory design. Data berupa hasil tes. Hasil penelitian ini, ditemukan bahwa $61 \%$ siswa mengalami kesalahan pada operasi penjumlahan pecahan dan $63,3 \%$ siswa pada operasi pengurangan pecahan. Kesalahan siswa meliputi kesalahan prosedur, kesalahan konsep, kesalahan dalam menyalahartikan petunjuk, kesalahan karena kecerobohan, kesalahan aplikasi, dan kesalahan belajar. Berdasarkan paparan data hasil pembahasan, dapat disimpulkan bahwa kesalahan siswa pada operasi penjumlahan pecahan mencapai $61 \%$ dan pada operasi pengurangan pecahan mencapai $63,3 \%$.
\end{abstract}

Kata kunci: kesalahan siswa, penjumlahan, pengurangan, pecahan.

Pecahan merupakan salah satu materi penting dalam matematika. Pecahan merupakan konsep yang dipelajari secara berkesinambungan sejak pendidikan dasar sampai pendidikan tinggi. Pecahan mencakup konsep-konsep dasar dan merupakan materi prasyarat untuk mempelajari dan memahami materi-materi dalam matematika, sehingga penguasaan siswa terhadap pecahan, terutama operasi hitung pecahan menjadi suatu keharusan. Namun hal ini bertolak belakang dengan apa yang terjadi di lapangan. Pecahan seringkali sulit bagi siswa baik pada tingkat dasar, menengah sampai tingkat perguruan tinggi (Suryowati, 2015; Petit, 2010). Hal ini juga didukung oleh Smith (2002) yang menyatakan bahwa tidak ada materi matematika di sekolah dasar yang sekaya, serumit, dan sesulit pecahan untuk diajarkan. Vinogradova (2013) menyebutkan bahwa sedikit siswa yang menyukai pecahan, 
siswa tingkat menengah cenderung memberikan perhatian lebih pada hal ini (walaupun tidak menyukainya). Adapun beberapa hasil penelitian yang mengatakan bahwa, penggunaan media blok pecahan dapat meningkatkan kemampuan penjum-lahan bilangan pecahan sederhana pada siswa (Utami, 2015; Halimah, 2015)

Dalam penelitiannya, Usodo (2001) menemukan beberapa faktor penyebab kesalahan siswa dalam menyelesaikan soal pecahan, salah satunya yaitu siswa tidak mengetahui algoritma yang tepat dalam menyelesaikan soal operasi hitung pecahan sehingga siswa tidak menyadari bahwa apa yang dilakukan dalam menyelesaikan soal merupakan sebuah kesalahan. Umar (2008:5) menemukan 11 dari 19 siswa kelas V SD mengalami kesulitan dalam mempelajari materi operasi penjumlahan dan pengurangan pecahan berpenyebut berbeda. Suryowati (2015) mengemukakan bahwa siswa memahami konsep pecahan tetapi siswa sulit merepresentasikannya dalam garis bilangan. Kesulitan ini dirasakan secara global, Vinogradova (2013) menyebutkan bahwa sedikit siswa yang menyukai pecahan, siswa tingkat menengah cenderung memberikan perhatian lebih pada hal ini (walaupun tidak menyukainya). Kesulitan yang dialami siswa di tingkat dasar mengakibatkan kurangnya pemahaman siswa pada tingkat berikutnya.

Berdasarkan hasil tes operasi penjumlahan dan pengurangan pecahan yang dilakukan pada beberapa siswa kelas VIII di kota Malang, ditemukan kesalahan yang dilakukan siswa pada operasi penjumlahan dan pengurangan pecahan. Kesalahan tersebut ditunjukkan pada gambar di bawah ini.

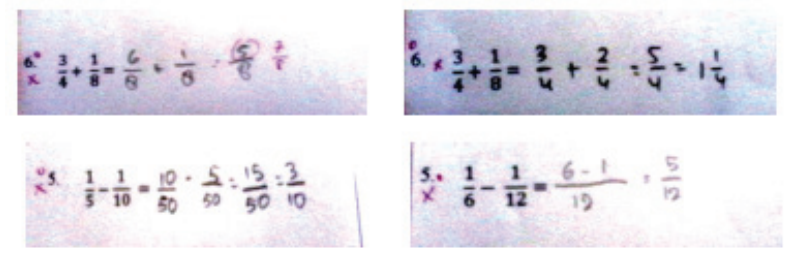

Gambar 1 Kesalahan Siswa Kelas VIII pada Penjumlahan dan Pengurangan Pecahan

Hasil wawancara pada siswa setelah tes menunjukkan bahwa kesalahan yang mereka alami dikarenakan siswa kurang teliti atau bingung dan lupa cara menyelesaikan operasi penjumlahan dan pengurangan pecahan, terutama dengan penyebut berbeda. Hasil ini tentu saja menarik, mengingat materi penjumlahan dan pengurangan pecahan telah dikenalkan pada siswa sejak tingkat SD.

Hasil observasi di atas, dapat digunakan sebagai evaluasi pada pembelajaran penjumlahan dan pengurangan pecahan di tingkat sekolah dasar. Dalam melaksanakan pembelajaran tentunya guru melaksanakan strategi yang berbeda (In'am, 2012). Hal ini karena kesadaran guru bahwa peserta didik tidak mempunyai kemampuan yang sama dalam menangkap materi yang diajarkan. Bray (2011) mengungkapkan bahwa guru di tingkat sekolah dasar seringkali memperhatikan jawaban siswa yang benar, akan tetapi mengabaikan kesalahan yang dilakukan siswa.

Hasil penelitian ini diharapkan dapat digunakan sebagai bahan pertimbangan dalam menyusun pembelajaran dan diharapkan dapat meningkatkan kegiatan belajar siswa yang lebih lanjut serta memperbaiki hasil belajar atau prestasi belajar siswa.

Permasalahan dalam penelitian ini adalah apa saja kesalahan siswa kelas VI sekolah dasar pada operasi penjumlahan dan pengurangan pecahan serta faktor penyebab kesalahan tersebut. Sehingga, tujuan dari penelitian ini adalah untuk mendeskripsikan kesalahan siswa kelas VI sekolah dasar pada operasi penjumlahan dan pengurangan pecahan serta faktor penyebab kesalahan tersebut.

\section{Kesalahan dalam Matematika}

Kesalahan dapat dipandang sebagai kesempatan untuk refleksi dan belajar. Idris (2011) mengungkapkan bahwa kesalahan merupakan sesuatu yang mendasar dan positif dalam proses belajar. Namun kenyataannya, kesalahan juga dapat menurunkan rasa percaya diri siswa dalam menyelesaikan masalah sehingga dapat berakibat pada menurunnya kemampuan siswa. Swan (2001) mengungkapkan kesalahan manusia dapat dilihat dari berbagai alasan, karena kurangnya konsentrasi, pemikiran yang terburu-buru, memori yang penuh atau kegagalan mencatat hal-hal yang penting ketika belajar. Ketika hasilnya tidak berkaitan dengan tujuan yang diharapkan saat itulah terjadi kesalahan hasil; ketika tindakan yang dilakukan tidak sesuai dengan prosedur yang diterima, saat itulah terjadi kesalahan tindakan.

Nolting (2011:116) mengemukakan enam tipe kesalahan dalam mengerjakan tes berikut ini. Pertama, kesalahan dalam menyalahartikan petunjuk 
(misread direction errors): kesalahan diduga terjadi ketika mengabaikan petunjuk atau salah dalam memahami petunjuk. Kedua, kesalahan karena kecerobohan (careless error): kesalahan diduga dapat dilihat secara otomatis saat mengecek hasil tes. Ketiga, kesalahan konsep (concept errors): kesalahan diduga terjadi ketika tidak memahami prinsip/sifat yang dibutuhkan untuk menyelesaikan tes.

Keempat, kesalahan aplikasi (application errors): kesalahan diduga terjadi ketika memahami konsep namun tidak dapat mengaplikasikannya dalam penyelesaian masalah. Kelima, kesalahan prosedur tes (test procedure errors): kesalahan diduga terjadi karena beberapa langkah yang dilakukan saat mengerjakan tes, seperti: melewatkan bagian pertanyaan; tidak melengkapi jawaban sampai langkah terakhir; mengubah jawaban yang sudah benar menjadi tidak benar; berkutat dalam satu pertanyaan dan menghabiskan terlalu banyak waktu disana; tergesa-gesa, menyelesaikan soal yang mudah dan membuat kecerobohan; salah dalam menyalin jawaban dari kertas buram; tidak menjawab. Keenam, kesalahan belajar (study errors): kesalahan diduga terjadi ketika siswa mempelajari materi yang salah atau tidak meluangkan waktu yang cukup untuk mempelajari materi yang seharusnya.

\section{METODE}

Penelitian ini menggunakan rancangan eksplanatori (Clark \& Cresswell, 2007). Rancangan ini dipilih karena tujuan penelitian untuk mengidentifikasi kesalahan siswa dalam penjumlahan dan pengurangan pecahan serta menjelaskan faktor penyebab kesalahan tersebut. Subjek pada penelitian adalah 67 siswa kelas VI dari SDN Kauman 1, SDN Penanggungan, dan SDN Jatimulyo 1. Penelitian diawali dengan pengumpulan dan analisis data kuantitatif. Data kuantitatif berupa hasil tes yang kemudian dianalisa berdasarkan kesalahan-kesalahan yang muncul dari jawaban siswa. Kesalahan tersebut kemudian diklasifikasikan dan diberikan penjelasan rinci tentang kesalahan-kesalahan tersebut.

Tes diagnostik yang diberikan kepada siswa diadaptasi dari tes yang diberikan Idris (2011) terdiri dari 8 butir soal penjumlahan pecahan (nomor 1-8) dan 7 butir soal pengurangan pecahan (nomor 9-15). Rancangan soal dapat dilihat pada tabel 1.

Berdasarkan hasil kuantitatif akan diseleksi subjek yang menjadi partisipan kualitatif. Pada penelitian ini dipilih 6 siswa yang mewakili kesalahan yang muncul baik pada operasi penjumlahan maupun pengurangan pecahan. Siswa tersebut kemudian diwawancara untuk mengetahui lebih lanjut penyebab kesalahan yang dilakukannya. Setelah dilakukan analisa data kualitatif maka diakhiri dengan interpretasi kuantitatif serta kualitatif.

\section{HASIL DAN PEMBAHASAN}

\section{Hasil}

Penelitian dilaksanakan pada tiga sekolah dasar negeri yang berada di kota Malang pada bulan Oktober 2015. Tes diagnostik diberikan pada 67 siswa kelas VI SD. Berdasarkan hasil tes tersebut, diperoleh persentase kesalahan pada penjumlahan pecahan, yang dapat dilihat pada tabel 2 .

Pada tabel 2, diketahui bahwa kesalahan siswa terbanyak pada soal nomor 8 sedangkan kesalahan terkecil ada pada soal nomor 1. Pada penyelesaian soal nomor 1, sebagian besar siswa telah mampu menyamakan penyebut dan menentukan pembilang dengan benar. Kesalahan siswa umumnya terjadi karena siswa kurang teliti saat menyamakan penyebut, serta ada beberapa siswa yang langsung menjumlahkan pembilang dengan pembilang dan penyebut dengan penyebut. Pada penyelesaian soal nomor 8, terdapat 40 jenis jawaban yang diberikan siswa. Kesalahan yang umumnya dilakukan siswa antara lain karena siswa tidak menyederhanakan sampai bentuk pecahan campuran kembali; siswa kurang teliti dalam menuliskan hasil akhir; siswa menyamakan penyebut tanpa mengubah nilai pembilangnya, dsb. Penyelesaian soal nomor 8 yang beragam ini, menunjukkan bahwa siswa mengalami kesulitan dalam menyelesaikan penjumlahan pecahan campuran yang hasilnya memerlukan penyederhanaan (lihat tabel 3).

Secara umum persentase kesalahan yang dilakukan siswa pada pengurangan pecahan lebih besardaripada pada penjumlahan pecahan. Pada tabel 3, dapat diketahui bahwa kesalahan siswa terbanyak pada soal nomor 15 sedangkan kesalahan terkecil pada soal nomor 9. Pada penyelesaian soal nomor 9, sebagian besar siswa sudah mampu menentukan hasil dengan prosedur yang tepat. Kesalahan yang dilakukan siswa pada penyelesaian soal nomor 9 ini umumnya tidak menyelesaikan sampai bentuk paling sederhana, kesalahan lainnya bervariasi 
Tabel 1. Rancangan Butir Soal Tes pada Penjumlahan dan Pengurangan Pecahan

\begin{tabular}{|c|c|c|c|}
\hline & Penjumlahan Pecahan & & Pengurangan Pecahan \\
\hline a) & Penjumlahan pecahan biasa berpenyebut berbeda. & a) & Pengurangan pecahan biasa berpenyebut berbeda. \\
\hline b) & Tidak dapat disederhanakan. & b) & Tidak dapat disederhanakan \\
\hline a) & Penjumlahan pecahan biasa berpenyebut berbeda. & a) & Pengurangan pecahan biasa berpenyebut berbeda. \\
\hline b) & Dapat disederhanakan. & b) & Dapat disederhanakan \\
\hline a) & Penjumlahan pecahan biasa berpenyebut berbeda. & a) & Pengurangan pecahan biasa dari bilangan bulat. \\
\hline b) & Tidak dapat disederhanakan. & b) & Tidak dapat disederhanakan. \\
\hline c) & Jawaban dapat diubah menjadi pecahan campuran. & c) & Jawaban dapat diubah menjadi pecahan campuran. \\
\hline a) & Penjumlahan pecahan biasa berpenyebut berbeda. & a) & Pengurangan pecahan campuran dengan pecahan \\
\hline b) & Dapat disederhanakan. & & biasa berpenyebut berbeda. \\
\hline \multirow[t]{2}{*}{ c) } & Jawaban dapat diubah menjadi pecahan campuran. & b) & Tidak dapat disederhanakan. \\
\hline & & c) & Jawaban dapat diubah menjadi pecahan campuran \\
\hline a) & $\begin{array}{l}\text { Penjumlahan pecahan campuran dengan pecahan } \\
\text { biasa berpenyebut berbeda. }\end{array}$ & a) & $\begin{array}{l}\text { Pengurangan pecahan campuran dengan pecahan } \\
\text { biasa. }\end{array}$ \\
\hline b) & Tidak dapat disederhanakan. & b) & Dapat disederhanakan. \\
\hline c) & Jawaban dapat diubah menjadi pecahan campuran. & c) & Jawaban dapat diubah menjadi pecahan campuran. \\
\hline a) & $\begin{array}{l}\text { Penjumlahan pecahan campuran dengan pecahan } \\
\text { biasa. }\end{array}$ & a) & $\begin{array}{l}\text { Pengurangan pecahan campuran dengan pecahan } \\
\text { campuran. }\end{array}$ \\
\hline b) & Dapat disederhanakan. & b) & Tidak dapat disederhanakan. \\
\hline c) & Jawaban dapat diubah menjadi pecahan campuran. & c) & Jawaban dapat diubah menjadi pecahan campuran.. \\
\hline a) & $\begin{array}{l}\text { Penjumlahan pecahan campuran dengan pecahan } \\
\text { campuran. }\end{array}$ & a) & $\begin{array}{l}\text { Pengurangan pecahan campuran dengan pecahan } \\
\text { campuran. }\end{array}$ \\
\hline b) & Tidak dapat disederhanakan. & b) & Dapat disederhanakan. \\
\hline c) & Jawaban dapat diubah menjadi pecahan campuran. & c) & Jawaban dapat diubah menjadi pecahan campuran. \\
\hline a) & $\begin{array}{l}\text { Penjumlahan pecahan campuran dengan pecahan } \\
\text { campuran. }\end{array}$ & & \\
\hline b) & Dapat disederhanakan. & & \\
\hline c) & Jawaban dapat diubah menjadi pecahan campuran. & & \\
\hline
\end{tabular}

Tabel 2. Persentase Kesalahan Hasil Tes Diagnostik Penjumlahan Pecahan

\begin{tabular}{cccccccc}
\hline \multirow{2}{*}{ Nomor Soal } & \multicolumn{2}{c}{ Banyak Jawaban Tidak Tepat } & \multicolumn{3}{c}{ Persentase } & \multirow{2}{*}{ Persentase total } \\
\cline { 2 - 6 } & SDN J & SDN P & SDN K & SDN J & SDN P & SDN K & \\
\hline $\mathbf{1}$ & 3 & 2 & 7 & $30.0 \%$ & $7.7 \%$ & $22.6 \%$ & $17.9 \%$ \\
$\mathbf{2}$ & 8 & 14 & 12 & $80.0 \%$ & $53.8 \%$ & $38.7 \%$ & $50.7 \%$ \\
$\mathbf{3}$ & 10 & 12 & 19 & $100.0 \%$ & $46.2 \%$ & $61.3 \%$ & $61.2 \%$ \\
$\mathbf{4}$ & 10 & 17 & 23 & $100.0 \%$ & $65.4 \%$ & $74.2 \%$ & $74.6 \%$ \\
$\mathbf{5}$ & 10 & 13 & 20 & $100.0 \%$ & $50.0 \%$ & $64.5 \%$ & $64.2 \%$ \\
$\mathbf{6}$ & 10 & 17 & 22 & $100.0 \%$ & $65.4 \%$ & $71.0 \%$ & $73.1 \%$ \\
$\mathbf{7}$ & 10 & 15 & 18 & $100.0 \%$ & $57.7 \%$ & $58.1 \%$ & $64.2 \%$ \\
$\mathbf{8}$ & 10 & 19 & 26 & $100.0 \%$ & $73.1 \%$ & $83.9 \%$ & $82.1 \%$ \\
\hline
\end{tabular}

Keterangan tabel:

SDN J: SDN Jatimulyo 1

SDN P: SDN Penanggungan

SDN K: SDN Kauman 1 
Tabel 3. Persentase Kesalahan Hasil Tes Diagnostik Pengurangan Pecahan

\begin{tabular}{cccccccc}
\hline \multirow{2}{*}{ Nomor Soal } & \multicolumn{3}{c}{ Banyak Jawaban Tidak Tepat } & \multicolumn{3}{c}{ Persentase } & \multirow{2}{*}{ Persentase total } \\
\cline { 2 - 6 } & SDN J & SDN P & SDN K & SDN J & SDN P & SDN K & \\
\hline $\mathbf{9}$ & 7 & 8 & 5 & $70.0 \%$ & $30.8 \%$ & $16.1 \%$ & $29.9 \%$ \\
$\mathbf{1 0}$ & 7 & 13 & 9 & $70.0 \%$ & $50.0 \%$ & $29.0 \%$ & $43.3 \%$ \\
$\mathbf{1 1}$ & 10 & 16 & 26 & $100.0 \%$ & $61.5 \%$ & $83.9 \%$ & $77.6 \%$ \\
$\mathbf{1 2}$ & 10 & 13 & 18 & $100.0 \%$ & $50.0 \%$ & $58.1 \%$ & $61.2 \%$ \\
$\mathbf{1 3}$ & 10 & 17 & 25 & $100.0 \%$ & $65.4 \%$ & $80.6 \%$ & $77.6 \%$ \\
$\mathbf{1 4}$ & 10 & 16 & 23 & $100.0 \%$ & $61.5 \%$ & $74.2 \%$ & $73.1 \%$ \\
$\mathbf{1 5}$ & 10 & 20 & 24 & $100.0 \%$ & $76.9 \%$ & $77.4 \%$ & $80.6 \%$ \\
\hline
\end{tabular}

Keterangan tabel:

SDN J: SDN Jatimulyo 1

SDN P: SDN Penanggungan

SDN K: SDN Kauman 1

karena kesalahan konsep, prosedur, maupun kecerobohan dalam menghitung. Pada penyelesaian soal nomor 15 , diketahui bahwa kesalahan siswa bervariasi, $12 \%$ siswa tidak menjawab, $12 \%$ siswa tidak menyederhanakan jawaban, dan sisanya melakukan kesalahan acak. Kesalahan siswa pada nomor ini memberikan gambaran bahwa siswa masih kesulitan dalam menyelesaikan operasi, baik penjumlahan maupun pengurangan, yang berkaitan dengan pecahan campuran yang memerlukan penyederhanaan.

Hasil wawancara menunjukkan bahwa secara umum siswa memahami prosedur penyelesaian operasi penjumlahan dan pengurangan pecahan. Akan tetapi, siswa kurang teliti dalam proses penyelesaian tersebut. Hasil perkalian dan KPK dua bilangan seringkali menjadi masalah dalam kesalahan tersebut. Adapula siswa yang belum memahami prosedur serta konsepnya, sehingga pada suatu soal benar tetapi pada soal lainnya siswa menggunakan prosedur yang kurang tepat.

\section{PEMBAHASAN}

Hasil tes diagnostik menunjukkan $61 \%$ siswa mengalami kesalahan pada operasi penjumlahan dan 63,3\% siswa melakukan kesalahan pada operasi pengurangan dari total jawaban yang diberikan siswa. Kesalahan yang paling sering ditemui adalah kesalahan karena siswa tidak menyederhanakan jawaban terakhir. Berdasarkan hasil pekerjaan siswa, jawaban yang diberikan sudah benar akan tetapi belum dituliskan dalam bentuk paling sederhana sesuai petunjuk soal. Menurut Nolting
(2011) kesalahan ini diduga terjadi karena siswa mengabaikan petunjuk pada soal sehingga termasuk dalam kesalahan dalam menyalahartikan petunjuk. Hasil ini sesuai dengan hasil penelitian Idris (2011) yang menemukan bahwa kesalahan siswa salah satunya disebabkan karena tidak menyederhanakan sampai bentuk paling sederhana.

Kesalahan lain yang muncul pada penelitian Idris (2011) antara lain kesalahan karena kecerobohan, kesalahan dalam memahami soal, serta kesalahan dalam menyelesaikan pecahan campuran. Kesalahan ini juga ditemukan pada hasil tes diagnostik yang dilakukan. Kesalahan karena kecerobohan disebabkan siswa kurang teliti saat menyelesaikan proses perhitungan. Siswa juga seringkali keliru dalam mengubah pecahan biasa menjadi pecahan campuran, dan sebaliknya pada hasil akhir mereka. San Pedro, et al, (2014) mengungkapkan keunikan dalam kategori siswa yang melakukan kesalahan karena kecerobohan. Penelitian mereka pada tahun 2014 menghasilkan temuan yang mencengangkan. Siswa yang ceroboh dan mengalami kesalahan seringkali adalah siswa yang tampak antusias dalam belajar. Sebaliknya, siswa yang malas dan bosan selama pembelajaran mengalami kesalahan akibat kecerobohan lebih sedikit. Hal ini menunjukkan bahwa kemungkinan besar siswa yang melakukan kecerobohan dalam menjawab memang kurang memahami jawaban tersebut.

Kesalahan lain yang mendominasi pada hasil tes diagnostik siswa, baik pada operasi penjumlahan maupun pengurangan, adalah kesalahan terjadi pada soal atau jawaban yang berbentuk pecahan campuran. Kesalahan ini terjadi saat siswa mema- 
hami konsep yang berkaitan dengan soal tersebut, seperti disebutkan bahwa siswa memahami cara mengubah pecahan campuran ke pecahan biasa adalah bawah kali samping tambah atas, akan tetapi siswa tidak dapat mengaplikasikan konsep tersebut pada soal. Kesalahan siswa ini disebut kesalahan aplikasi (Nolting, 2011:117).

Kesalahan siswa lainnya, seperti kesalahan dalam menyamakan penyebut dan menentukan pembilang baru. Beberapa siswa menuturkan bahwa dalam operasi penjumlahan/pengurangan penyebut perlu disamakan dengan KPK-nya. Tetapi jawaban yang diberikan siswa masih kurang tepat, seperti KPK 8 dan 5 adalah 50. Siswa lain mengungkapkan penyebut baru diperoleh dari KPK penyebut awal namun pada kenyataannya siswa mengalikan penyebut awal bukan mencari KPK nya, bahkan ada yang menjadikan faktornya sebagai penyebut baru. Adapun kesalahan yang terjadi karena siswa menjumlahkan pembilang dengan pembilang dan penyebut dengan penyebut.

Jawaban yang diberikan oleh siswa dalam menentukan pembilang baru dengan cara menjumlahkan/mengurangkan pembilang awal dengan faktor pengalinya atau pembilang baru dihitung dengan melakukan perkalian silang antara pembilang dan penyebut dari pecahan pertama dan kedua. Hal inilah yang menjadi penyebab kesalahan siswa dalam menentukan pembilang baru dalam menyelesaikan penjumlahan/pengurangan pecahan. Kesalahan dalam menyamakan penyebut dan menentukan pembilang baru ini termasuk dalam kesalahan konsep (Nolting, 2011:117).

Beberapa siswa tidak menjawab soal yang mereka rasa sulit. Menurut Nolting (2011:117), hal ini termasuk dalam kesalahan prosedur. Kesalahan lain yang perlu disadari adalah adanya kesalahan belajar akibat siswa mengikuti bimbingan di luar sekolah. Hal ini ditengarai menjadi penyebab siswa melakukan kesalahan dalam menyelesaikan soal pecahan. Ketika siswa fokus mengikuti metode yang kurang tepat, dalam hal ini siswa menyamakan penyebut dengan faktor dari penyebut awal, berakibat kesalahan yang muncul pada jawaban siswa. Hal ini menunjukkan bahwa siswa seringkali terlalu focus dengan hafalan rumus dan mengabaikan konsep yang telah mereka pahami sebelumnya (Zientek, et al, 2014).

Penyebab kesalahan siswa pada penjumlahan dan pengurangan pecahan, antara lain karena siswa tidak menyederhanakan jawaban akhir; siswa memahami konsep mengubah pecahan campuran menjadi pecahan biasa, dan sebaliknya namun lemah dalam aplikasinya; siswa masih lambat dalam menyelesaikan operasi perkalian 2 bilangan (terutama antara bilangan 1 s.d. 10); siswa kurang memahami KPK; siswa kurang memahami konsep penyelesaian penjumlahan/pengurangan pecahan berpenyebut berbeda; dan siswa kurang teliti dalam menyelesaikan perhitungan. Faktor penyebab ini perlu mendapatkan perhatian dalam pembelajaran. Hal ini dikarenakan pecahan merupakan materi yang diajarkan pada tingkat dasar sampai tingkat menengah. Kesalahan siswa yang tidak segera menemukan solusi akan menyebabkan kesalahan siswa pada pembelajaran pecahan di tingkat berikutnya (Tiun, dkk, 2014).

Kesalahan yang muncul dalam penelitian ini serupa dengan kesalahan siswa yang muncul pada diagnosis (Untari, 2014). Menurut Untari (2014) siswa diharapkan memaksimalkan sumber belajar yang disediakan guru sehingga tidak muncul kesalahan dalam belajar. Selain itu, guru perlu memberikan pembelajaran yang memaksimalkan pemahaman siswa terhadap konsep oprasi pecahan. Nolting (2011:116-118) menyebutkan bahwa kesalahan yang muncul pada hasil tes siswa dapat diatasi dengan membaca semua petunjuk soal dengan teliti; belajar kembali materi yang belum dipahami dengan efektif; mencoba mengaplikasikan konsep yang dipelajari sehingga terbiasa; dan terus mencoba mengatasi kesulitan saat menyelesaikan soal.

Di lain pihak, cara guru dalam menangani kesalahan siswa juga berpengaruh dalam mengatasi kesalahan yang dilakukan siswa. Cara guru dalam menangani kesalahan siswa dapat dipengaruhi oleh pengetahuan dan kepercayaan guru dalam mengajarkan matematika (Bray, 2011). Cara guru dalam mengatasi kesalahan yang muncul dari siswa dapat diorganisasikan dalam praktek pengajaran yang memunculkan kolaborasi dari pengetahuan dan kepercayaan guru dalam mengajarkan suatu konsep matematika. Selain itu, Marhamah, dkk, (2014) mengungkapkan bahwa materi ajar pecahan dengan pendekatan PMRI dapat memberikan efek positif dalam pembelajaran pecahan. Hal ini menunjukkan bahwa pembelajaran pecahan di sekolah dasar juga perlu dikembangkan dengan menggunakan pendekatan yang tepat. 


\section{SIMPULAN DAN SARAN}

\section{Simpulan}

Berdasarkan paparan data dan hasil pembahasan, dapat disimpulkan bahwa kesalahan siswa pada operasi penjumlahan pecahan mencapai $61 \%$ dan pada operasi pengurangan pecahan mencapai $63,3 \%$. Kesalahan ini meliputi

(a) kesalahan siswa menyalahartikan petunjuk (siswa mengabaikan petunjuk soal bahwa jawaban yang diminta sampai pecahan paling sederhana); (b) kesalahan konsep (siswa kurang memahami KPK, salah dalam menentukan pembilang baru dan menyamakan penyebut); (c) kesalahan aplikasi (siswa memahami konsep mengubah pecahan campuran atau bilangan bulat dalam bentuk pecahan biasa, dan sebaliknya, namun mengalami kesalahan dalam aplikasinya pada soal); (d) kesalahan prosedur (tidak menjawab); (e) kesalahan belajar (memperoleh informasi yang salah saat belajar di luar sekolah); serta (f) kesalahan karena kecerobohan (kurang teliti dalam menyelesaikan hasil perhitungan).

Penyebab kesalahan siswa antara lain karena (a) siswa tidak menyederhanakan jawaban akhir; (b) siswa memahami konsep mengubah pecahan campuran menjadi pecahan biasa, dan sebaliknya namun lemah dalam aplikasinya; (c) siswa masih lambat dalam menyelesaikan operasi perkalian 2 bilangan (terutama antara bilangan 1 sampai 10); (d) siswa kurang memahami KPK; (e) siswa kurang memahami konsep penyelesaian penjumlahan/ pengurangan pecahan berpenyebut berbeda; dan (f) siswa kurang teliti dalam menyelesaikan perhitungan.

\section{Saran}

Penelitian ini memberikan informasi kesalahan siswa pada penjumlahan dan pengurangan pecahan. Hasil penelitian dapat dijadikan landasan serta referensi bagi tenaga pendidik serta peneliti berikutnya untuk mengembangkan pembelajaran pecahan serta menggali proses berpikir atau jenis kesalahan lain yang dialami siswa. Hal ini sebagai langkah antisipasi untuk tingkat berikutnya, sekaligus revisi pada pembelajaran pecahan di tingkat dasar.

\section{DAFTAR RUJUKAN}

Bray, W. S. 2011. A Collective Case Study of The Influence of Teachers' Beliefs and Knowledge on Error-Handling Practices During Class Discussion of Mathematics. Journal for Research in Mathematics Education, 42(1), 2-38.

Creswell. J. W. \& Clark, Vicki L.P. 2007. Designing and Conducting Mixed Methods Research. California: Sage Publications, Inc.

Halimah, I.N., Poerwanti, J.I.S., \& Djaelani. 2015. Penggunaan Media Blok Pecahan untuk Meningkatkan Kemampuan Penjumlahan Bilangan Pecahan Sederhana. Jurnal Pendidikan Dasar. 1 (1), 1-6

Idris, N. \& Narayanan, L. M. 2011. Error Patterns in Addition and Subtraction of Fractions among Form Two Students. Journal of Mathematics Education, 4(2), 35-54.

In'am. 2012. Perspektif Metakognitif Guru dalam Pembelajaran Matematika di Sekolah Dasar. Sekolah Dasar Kajian Teori dan Praktik Pendidikan, 21(2), 133-144.

Marhamah, M., Zulkardi, Z., \& Aisyah, N. 2014. Pengembangan Materi Ajar Pecahan dengan Pendekatan PMRI di SD Negeri 21 Palembang. Jurnal Pendidikan Matematika, 5(2).

Nolting, P. D. 2011. Math Study Skill Workbook $4^{\text {th }}$ Edition. Cengage Learning.

Petit, M. M. 2010. A focus on Fraction: Bringing Research to The Classroom. Routledge: New York.

San Pedro, M. O. Z., d Baker, R. S., \& Rodrigo, M. M. T. 2014. Carelessness and Affect in an Intelligent Tutoring System for Mathematics. International Journal of Artificial Intelligence in Education, 24(2), 189-210.

Smith III, J. P. 2002. The Development of Students' Knowledge of Fractions and Ratios. Making Sense of Fractions, Ratios, and Proportions. NCTM.

Suryowati, E. 2015. Kesalahan Siswa Sekolah Dasar dalam Merepresentasikan Pecahan pada Garis Bilangan. Aksioma. 4(1), 38-52.

Swan, A. 2001. Dealing with Misconseption in Mathematics. Issues in Mathematics. Routledge: New York and London. 
Tiun, P. K., Hudiono, B., \& Hartoyo, A. (2014). Kemampuan Pemecahan Masalah dan Komunikasi Matematis Siswa Menyelesaikan Soal Cerita Materi Pecahan di SMP. Jurnal Pendidikan dan Pembelajaran, 3(8).

Umar, W. 2008. Mengkonstruksi Pembelajaran Matematika dengan Media Berdasarkan Hasil Diagnosis Kesulias Siswa dalam Mempelajari Operasi Pecahan. Tesis tidak diterbitkan. Malang: Pascasarjana Universitas Negeri Malang.

Untari, E. 2014. Diagnosis Kesulitan Belajar Pokok Bahasan Pecahan pada Siswa Kelas V Sekolah Dasar. Jurnal Ilmiah STKIP PGRI Ngawi, 13(1), 1-8.

Usodo, B. 2001. Diagnosis Kesulitan Belajar Topik Pecahan dan Alternatif Pemecahannya. Tesis tidak dipublikasikan. Surabaya: Pascasarjana Universitas Negeri Surabaya.
Utami, L. 2015. Analisis Kesulitan Siswa SMP Kelas VII dalam Menyelesaikan Soal Operasi Hitng Bilangan dan Solusi Pemecahannya. Konferensi Nasional Penelitian Matematika dan Pembelajarannya. Tanggal 12 Maret 2016.

Vinogradova, N. \& Larry, B. 2013. The Maximum Chocolate Party Game Requires Students to Divide and Compare Fraction in A Practical and Concrete Context. JRME. (Online), (http://www. nctm.org/ publications/ article.aspx?id=35833, diakses via internet pada 11 April 2013)

Zientek, L. R., Schneider, C. L., \& Onwuegbuzie, A. J. 2014. Instructors' Perceptions about Student Success and Placement in Developmental Mathematics Courses. The Community College Enterprise, 20(1), 66. 